In summary, the immunologist needs no special inducement to read this essay, for he will do so anyway; but it is important that every biologist interested in the problems of cellular heredity and transformation should be aware of the rather direct bearing of antibody formation upon them.

\section{A LIFETIME'S WORK ON TROPICAL MEDICINE}

Happy Toil

Fifty-five Years of Tropical Medicine. By MajorGeneral Sir Leonard Rogers. Pp. xvi+271+8 plates. (London: Frederick Muller, Ltd., 1950.) 18s. net.

A BOOK such as "Happy Toil" could only have been written by a Happy Warrior, and that in the person of Sir Leonard Rogers. It therefore follows that it supplies a record, breathing of that zest and burning enthusiasm which have emanated from his person throughout his long life. Sir Leonard's personality is engraven on every word, whether we pursue him on his bicycle scudding up and down impossible mountains or dodging elephants and leopards in his path. It is the same indomitable spirit which enabled him to flout conventions, to beard authority in its den, to discard his uniform whenever possible, and to refuse to budge one iota. from his principles in order to placate his fellow men, but which finally enabled him to triumph over every conceivable obstacle.

This book has the spirit which led to discoveries of the first order, and in this category must be placed his researches on amœbiasis and that extraordinary reasoning which enabled him to place emetine treatment on a scientific basis. Next in order of importance must come his clarification of the life-history of Leishmania and the application of antimony therapy to the treatment of kala-azar. Although we may not all agree with his physiological tenets, nevertheless he introduced a new principle in the treatment of cholera. All the world knows of his struggles in the treatment of that hideous mutilating disease-leprosy. Throughout it all, Sir Leonard's superoptimism has carried him through, so that no one can deny that, as the result of his foundation of the British Empire Leprosy Relief Association, the lot of the leper has been revolutionized and the stendard of treatment much improved.

Some, indeed, may cavil at the sweeping conclusions he has deduced from most intense, detailed and laborious studies in official blue books. In these he juggles with columns of figures on the incidence of cholera, pneumonia and smallpox in India. It might be suggested that sometimes the figures and methods of their assessment are not always reliable; but this has not deterred him from arriving at definite conclusions regarding the forecasting of epidemics.

There is no one who has possessed the drive, energy, enthusiasm and business capacity of Sir Leonard-or indeed one who could have extracted such large sums from the official and business circles of Calcutta. The School of Tropical Medicine there, together with the Carmichael Hospital for Tropical Diseases, will for ever stand as memorials to the memory of this great Englishman. That he is brave and determined has been shown on many occasions, in his handling of poisonous snakes, as well as in his successful battles against the anti-vivisectionists which graced the close of his career. There is a grand vein of optimism running through this book; but it could not be otherwise.

Sir Leonard would have you know that he has a profound divine faith and a deep belief in himself, his ancestry and his upbringing; he is also deeply conscious of his debt to science which he has repaid in generous gifts and in the value of the scientific work which he has so happily accomplished. He has penned a fine tribute to his wife, as is just, and his account of their courtship forms one of the most delightful interludes of his book. "No; she had not got cholera, but she had definitely got him."

Phillp Manson-Bahr

\section{HEAT FOR DEGREE STUDENTS}

A Textbook on Heat

By J. H. Awbery. Pp. $x+302$. (London, New York and Toronto : Longmans, Green and Co., Ltd., 1949.) 15s. net.

MOST teachers of physics are aware of the 1 importance of a sound knowledge of what is usually called classical physics. Classical physics, however, consists of the less spectacular and older branches, of which heat is one, and, in competition with the more attractive and rapidly advancing modern branches such as atomic physics or electronics, it nowadays receives inadequate treatment. This is due in no small part to the lack of suitable up-todate text-books. However admirable Preston's "Heat" may be, it nevertheless does not attract the present-day undergraduate. The volume under review is a contribution in the right direction. It is written by a recognized authority on heat and an experienced research worker, and the original and stimulating manner in which the material is presented should prove acceptable to most readers. In place of the traditional detailed treatment of the thermal behaviour of substances and somewhat elaborate descriptions of experimental arrangements, the author has concentrated on fundamental principles and has tried to state clearly and precisely what are the essential features of particular investigations.

From a discussion of temperature and its measurement, the volume proceeds to the point where heat is found to be measurable, and from there to the relation between heat and energy. The first and second laws of thermodynamies, the properties of gases, the phase rule, the properties of solids, thermal expansion, and the properties of liquids with change of phase are then dealt with in that order. Three chapters on heat transfer follow, and after a chapter on statistical mechanics the book concludes with a discussion of the applications of thermodynamics to heat engines and to chemistry.

The standard is stated to be that of the ordinary degree; but it varies greatly from chapter to chapter. For example, the chapter on thermal expansion is most elementary, but those on statistical mechanics, conduction and convection, in particular, are more suitable for an advanced honours course. In some places there are unnecessarily long and involved mathematical discussions as though the reader is expected to have only limited mathematical ability ; yet in other places second-order partial differential equations, Fourier series and the complex variable are introduced without much comment. 